\title{
DiRECT USE VALUES OF SELECTED VEGETATION RESOURCES in the Okavango Delta Wetland
}

\author{
G Mmopelwa and JN Blignaut \\ Department of Economics, University of Pretoria \\ R Hassan
}

Centre for Environmental Economics and Policy in Africa (CEEPA), University of Pretoria

\begin{abstract}
The economic benefits generated by wetlands and the costs associated with their degradation or loss are frequently overlooked. This often leads to decisions that stimulate wetland conversion and degradation. An important step towards correcting this situation and countering this neglect is to establish the true values of a wetland's ecosystem goods and services. This study attempts to estimate the direct use values of native plants, such as palm leaves for basketry, grass for thatching, fuelwood, edible fruits and plant parts used by three villages adjacent to the Okavango Delta during the 2003 calendar year. Other sources of ecosystem goods and services, such as fishing, floodplain farming and tourism, were not considered in this study. The average annual value per household of these harvested resources is generally higher than that of similar resources found in other southern African wetlands, owing to higher consumption rates. The overall total direct use value of plant resources, including household income contributions "in kind", was estimated at US\$1 434 per household for 2003 (or US $\$ 43.41 /$ ha). This value is almost equal to the average household financial income of US\$1 416/year. The net present value of the overall benefit from the direct use of the vegetative resources is estimated at US\$101.9 million. This clearly indicates the value of the use of natural resources and their contribution to livelihoods and quality of life. This value is so significant that economic development planners ought to incorporate it into development planning. They should not conceive infrastructure development that would jeopardise the communities' access to these natural resources without any well-developed mitigation strategy.
\end{abstract}

Keywords: Okavango Delta; economic value; ecosystem goods and services; plant resources; households

JEL Q25, 27, 51

\section{1}

\section{Introduction}

The Okavango Delta (also referred to here as the Delta) is one of the largest remaining inland wetland ecosystems in the world (Neme, 1997; Rothert, 1997; Silvius et al., 2000; Ashton et al., 2003; Gumbricht et al., 2004). The water source for the Delta is in the Angolan highlands, from whence the water flows in a south-easterly direction into the Okavango River. From here, it passes through the Caprivi Strip of Namibia before reaching the Delta in northern Botswana
(Schudder et al., 1993; Gumbricht et al., 2004). The Delta has a maximum area of approximately $22000 \mathrm{~km}^{2}$ (Monna, 1999). The total annual input of water into the Delta is estimated at $15339 \mathrm{Mm}^{3}$, of which $6144 \mathrm{Mm}^{3}$ are from rainfall. The potential evapotranspiration is estimated at $2172 \mathrm{~mm}$ (McCarthy, 1997). A unique characteristic of the Delta is that it does not flow to the sea. It starts and ends inland and is a unique and independent system (Ashton et al., 2003). The Delta supports an estimated 150000 inhabitants by supplying water for people and livestock, and, most important, 
supporting edible and medicinal plants, fishing, and conditions for floodplain farming (Rothert, 1997; Jansen, 2002; Ashton et al., 2003). Pursuing a diversity of livelihood activities gives households a way of reducing vulnerability during times of hardship and, increasingly, climate change. For example, households whose main livelihood activity is dry-land farming can resort to fishing and harvesting resources from the wild during prolonged periods of drought (Kgathi et al., 2004).

While the Okavango Delta has sustained local inhabitants through ecosystem goods and services for centuries, the functioning of the Delta's natural ecosystem has been threatened over the past two decades by several water "development" initiatives. For instance, in 1985, the Government of Botswana issued a Terms of Reference allowing the Southern Okavango Integrated Water Development Project (SOIWDP) to conduct a feasibility study on possible uses of the Delta's water, with minimal environmental impact. The specific goals were to provide up to 1000 ha of floodplain cultivation, commercial irrigation, improved fisheries, and water supply for the local communities (Schudder et al., 1993). These goals were to be achieved by means of an integrated scheme for surface water development. This would require channelling and bundling, as well as the construction of three reservoirs in the lower portion of the Delta (Snowy Mountains Engineering Corporation, 1987; Schudder et al., 1993). The reservoirs were intended to supply water to the towns of Maun and Orapa, provide $12 \mathrm{Mm}^{3} /$ year for irrigation, and provide flood irrigation for agriculture (Schudder et al., 1993). However, after an independent review of the proposed project by the World Conservation Union (IUCN) (requested by the government) and an outcry from local and international communities on the project's perceived negative impacts on the environment, the project was abandoned. Similarly, national water shortages in 1996 led Namibia's government to propose the construction of a $240 \mathrm{~km}$ pipeline to abstract 17 million $\mathrm{m}^{3}$ annually from the Okavango River where it passes through the Caprivi Strip, for use in central Namibia (Rothert, 1999; Ashton et al., 2003). This project has currently been suspended but not ruled out (Gumbricht et al., 2004). While in general economic literature such infrastructure development is considered economic development, it is likely to affect those who are dependent on the system. Such development is thus likely to have a tradeoff. In this study we estimate the value of this trade-off.

According to Emerton (1998), the economic benefits generated by wetlands and the costs associated with their degradation or loss are frequently overlooked, often leading to decisions that stimulate wetland conversion and degradation. One of the forces driving wetland degradation is the fact that most of the products and services of wetlands are not directly marketed. For this reason, policy-makers and private landowners do not typically receive a return on preservation of wetlands, despite the fact that they provide the society with valuable services (Boyer \& Polasky, 2004). Because of this obvious marketing failure it becomes even more important to estimate the economic values of ecosystem goods and services provided by wetlands to facilitate informed choices on the use of wetlands (Heal, 2004). The concept of "total economic value" provides a framework for the valuation of many environmental resources like wetlands (Barbier et al., 1997; Millennium Ecosystem Assessment, 2003; Brander et al., 2006). Total economic value is an aggregate of total use value and total non-use value. Use value can be divided into direct use value, indirect use value and options value. Direct use value refers to value derived from the use of raw materials and physical products from the wetland (Emerton, 1998). These values may be consumptive (e.g. harvesting wild food products for consumption) or non-consumptive (e.g. enjoying recreational and cultural amenities such as wildlife viewing) (Millennium Ecosystem Assessment, 2003). Indirect use value refers to the value associated with indirect services or functions of wetlands, such as storm protection, nutrient retention, microclimate stabilisation and maintenance of water quality (Brander et al., 2006). Option value is the premium placed on or the willingness to pay for maintaining the possibility of future use of a resource (Brander et al., 2006). Quasi-option value is the value of what 
people are willing to pay to avoid irreversible decisions until new information reveals whether certain ecosystems have currently unknown values (Millennium Ecosystem Assessment, 2003).

Non-use value can be divided into existence value and bequest value. Existence value is the value attached to knowing that an environmental asset exists even though the value attributer may not be interested in current or future consumption of the resource. Bequest value is the value that an individual derives from ensuring that the resources will be available for his or her heirs or future generations (Barbier et al., 1997; Turner et al., 2000). As noted earlier, the total economic value of a wetland is made up of a number of values. In principle, the total economic value of a resource can be used to justify its protection. However, in practice it is often difficult and costly to determine the total economic value of a resource because of the multifaceted economic values. Quite often, a partial valuation is done to show the values of different resources. The aim of this study is to estimate the direct use value in 2003 for three villages adjacent to the Okavango Delta of the various vegetative resources of the Okavango Delta, such as river reed, thatching grass, wild fruits and edible plant parts (mostly roots), fuel-wood, and palm leaves. These values were estimated according to household survey information, such as the average harvesting period, collection frequencies, the quantities of resources harvested and market prices. Based on the information gathered from these estimates, the use value for the Delta as a whole is estimated and the policy implications of the findings are derived.

\section{2}

\section{Study areas and research method}

\subsection{Study area}

This study was conducted in three villages adjacent to the Okavango Delta - Shakawe, Etsha-13 and Shorobe (see Figure 1) - where all the natural resources described in section 1 are harvested or extracted. Applied Development Research Consultants (2001) found that these natural resources are harvested in 21 villages. Shakawe is located within the water-abundant panhandle of the Delta, Etsha-13 is $10 \mathrm{~km}$ away on the eastern side of the Delta and the furthest, Shorobe, is situated about $20 \mathrm{~km}$ away in the southern part of the Delta. The Central Statistics Office (2001) estimated the population size of Shakawe at 4 389, Etsha-13 at 1975 and Shorobe at 955 . The average household size in this district is estimated at 4.7 (the national average is 4.3), and half of the population aged between 12 and 39 years (PLANTEC AFRICA, 2003). Life expectancy in the area is estimated at 55.7 years, the unemployment rate is 64 percent and the average household income in the area is P500/month (US\$118/month or US\$1 426/ year) (Government of Botswana, 2003; Applied Development Research Consultants, 2001).

As in most African societies, households in the Okavango Delta diversify their livelihood activities to reduce risk (Kgathi et al., 2004). These activities include livestock, dry-land and flood-plain farming, fishing, hunting, and gathering field products for the production and sale of crafts, as well as formal employment in the public, private and commercial sectors and tourism (PLANTEC AFRICA, 2003). Edible products from the wild provide an important supplement to their diet, especially during periods of food scarcity. This applies particularly to poor households, which, for the most part, are headed by women. Additional resources harvested from the wild include thatch, reeds and fuelwood, all of which are usually harvested for household consumption rather than for selling. This household livelihood supplement constitutes "in kind" income.

For all three villages, access to wetlands-based resources such as water, thatching grass and fish is mainly on an open-access system. Under such a system there are neither regulations on resource use nor ownership of resources by any person or institution (Pearce \& Turner, 1990; Prato, 1998). However, this does not hold true for land on the fringes of the Delta used for floodplain farming. Other prevailing but less dominant land tenure regimes include public property (where resource-use is controlled by the state) and common property (where the resources are owned and controlled by a defined 


\section{Figure 1}

Map of the Okavango Delta - the shaded areas indicate the three study sites

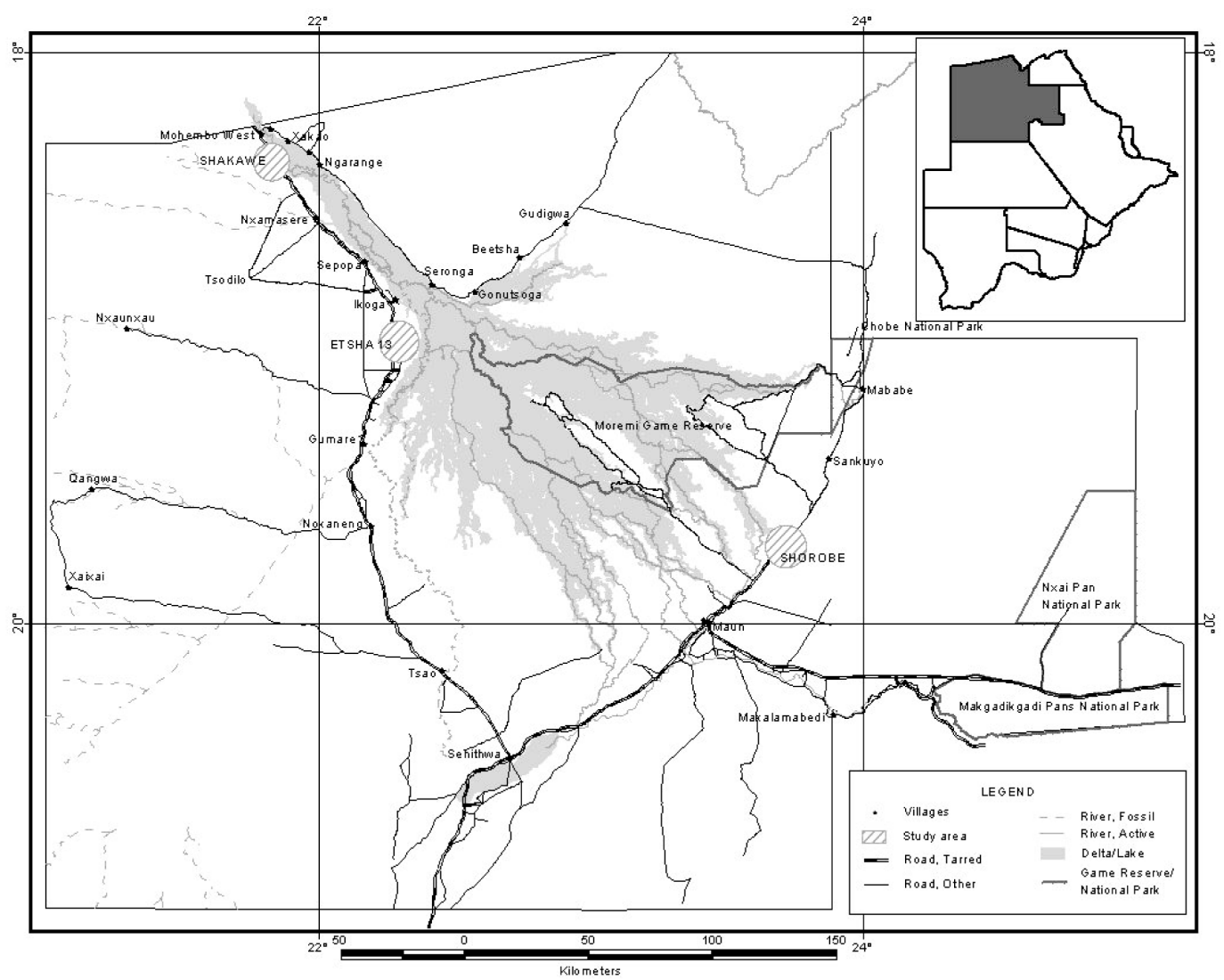

Source: Harry Oppenheimer Okavango Research Centre GIS Lab (published with permission)

group of people, such as a community, for the benefit of that group only).

The Delta is situated to the north of the Kalahari Desert (see Figure 1) in an arid to semi-arid summer rainfall area. The mean annual precipitation is $513 \mathrm{~mm}$ and the area is characterised by very high daytime temperatures, occasionally exceeding $40^{\circ} \mathrm{C}$ during the summer (Masundire et al., 1998). The Delta is surrounded by dry savanna, of which the composition and structure are heavily influenced by the various floodwater regimes. Some areas are perennially, seasonally or intermittently flooded, while other dryland areas are never flooded (Hudson-Murry \& Parry, 1997). The perennial swamps are characterised by tall reeds like Phragmites australis and P. mauritianus, and a wide variety of grasses and sedges (Government of Botswana, 2001). The dryland area is characterised by mixed stands of trees, grasses, shrubs and forbs. Vegetation on the small islands in the Delta includes Ficus verruculosa (water fig), Syzygium cordatum (water berry), tall, broad-leaved evergreen trees, such as Ficus natalensis (wild fig), Diospyros mespiliformis (African ebony), Garcinia livingstonei (African mangosteen) and Phoenix reclinata (wild date palm). The vegetation on the large islands and the sandveld tongues consists of open shrubland and woodland (Ellery \& Ellery, 1997).

\subsection{Research methods}

Primary data collection, using a household survey, was carried out between October and December in 2003. The survey included maps from the Botswana Population Census (CSO, 2001) to identify household dwellings. Each household dwelling had an enumeration area number, 
from which a sampling frame was constructed. The total sampling frame was comprised of 1683 households (1 096 household dwellings in Shakawe, 345 households in Etsha-13 and 242 households in Shorobe). A random sample was then drawn from each village for the purpose of this study. We selected 155 households (14 percent) from Shakawe, 55 (16 percent) from Etsha-13, and 45 (18 percent) from Shorobe, bringing the total to 255 households.

Using a structured questionnaire (developed at the Harry Oppenheimer Okavango Research Centre, University of Botswana), each selected household was interviewed using three enumerators. The researchers themselves oversaw the process. The questionnaire consisted of two sections. The first section collected sociodemographic information, while the second section focused on the types of resources harvested (reeds, thatching grass, wild fruits and edible plant parts, palm leaves and fuelwood); the species and volumes of harvest, harvest frequency, harvest season and location; the use of resources, whether or not the harvest was for the market, and the associated price if marketed.

\section{Direct use of extractive resources}

Estimating and valuing the quantities $(\mathrm{kg})$ of wild fruits and plant parts collected was problematic for a number of reasons. Firstly, harvesters usually collect wild fruits and edible plant parts for direct consumption, without recording quantities or volume. Secondly, some of the wild fruits and plants are not marketed or exchanged for other goods, making it difficult to determine their market value. Thirdly, wild fruits and plants may have substitutes, i.e. cultivated fruits sold in local shops, but these are of a different quality, so their prices do not reflect the true value of the wild fruits and plants. Despite these limitations, volumetric estimates of each type of fruit and plant resource were made using standard measuring containers. The unit weights of these measuring containers were then estimated. The aggregate annual harvests reported here is the product of the unit weight, the number of units harvested per week and the number of weeks in the harvesting period.

In the case of fuelwood, it is common knowledge that household consumption usually increases during the winter months (May, June and July). As the study was carried out during summer, the reported consumption figures represent an underestimation for the winter months. During focus group discussions, it was established that the consumption of fuelwood during winter months increased by 20-50 percent. To account for the increased consumption during winter, it was assumed that consumption increased by 30 percent.

\section{Economic values}

Determination of economic values involved the use of market prices (where the product was traded), and the value was estimated as the product of the price of the resource $(\mathrm{P})$, the quantities harvested annually $(\mathrm{Q})$ and the estimated number of households harvesting those resources (HH percent). In this context, the economic value is that of the direct use value of the resource, which refers to the benefit an individual derives from using or harvesting a particular resource. To estimate the total quantity of plant resources extracted in the entire Delta, three sets of information were used. For the first set, the average annual household consumption from the three villages in this study was estimated. For the second set, the number of households in these three villages harvesting the different resources was established using existing information such as the percentage of households harvesting these resources (Applied Development Research Consultants, 2001). For the third set, the number of households in all the villages surrounding the Delta consuming these resources was established, using information from the population census (CSO, 2001) and the figures from this study. The consumption figures estimated in this study can be used as proxies for all the households in villages around the Delta, as they share similar characteristics. In all cases, the direct cost of collecting or gathering these resources was negligible and was therefore assumed to be equal to zero. Given the high unemployment rate and the fact that unemployed people with little or no hope of finding employment harvest the resources, the shadow price of labour (the price imputed or adjusted as opposed to being taken directly from the market, which may not reflect the 
opportunity cost of the resource because of the presence of market distortions) can also be considered equal to zero (also see Mmopelwa, 2006).

\section{Net present value}

The net present value (NPV) of these resources was also estimated on the basis that these resources yield an annual flow of non-monetary, or "in-kind", values. If this annual value flow is expected to continue indefinitely or for as long as the resource is utilised sustainably (which is presumably the case if it is used only by the local people and not for large-scale industrial or agricultural expansion) then the relationship between net present value and the discount rate can be expressed as NPV = Yearly Flow/ Discount rate (Stuip et al., 2002). To determine the net present value of the resource, the annual direct use values were therefore divided by a discount rate of 8 percent, which falls within the discount rate range used by most impact assessments in Botswana.

\section{3 \\ Results}

\subsection{Socio-economic profile of the harvesters}

Seventy-five percent of the respondents were female and 25 percent were male. The average family size of the harvesting household was 6 persons, which is higher than the national average of 4.3. The respondents ranged in age from 17-86, which showed clearly that some elderly people still depend on natural resources for their livelihood. More than half (63 percent) of the respondents had no formal education.

\subsection{Use of vegetative resources: Results for the three study sites}

Table 1 shows the portion of households that harvest different vegetative resources in the three villages studied. More than 90 percent of the households harvest fuelwood. This emphasises the importance of wood as a source of energy, especially for the many households who cannot afford to pay for electricity or electrical appliances. Fuelwood is followed by thatching grass and river reed in terms of their economic importance, as these are used by more than 60 percent of the households.

Table 1

Percentage of households harvesting vegetative resources in the Delta

\begin{tabular}{|l|c|c|c|c|}
\hline \multirow{2}{*}{ Resource } & \multicolumn{3}{|c|}{ Village } & \multirow{2}{*}{$\begin{array}{c}\text { Weighted } \\
\text { average }\end{array}$} \\
\cline { 2 - 5 } & Shakawe & Etsha-13 & Shorobe & 92.4 \\
\hline Fuelwood & 92 & 98 & 87 & 67.9 \\
River reed & 81 & 67 & 24 & 62.6 \\
Thatching grass & 81 & 49 & 16 & 31.3 \\
Palm leaves & 27 & 42 & 33 & 33.5 \\
Wild fruits and edible plant parts & 45 & 25 & 4 & \\
\hline
\end{tabular}

\section{River reed}

Two species of river reed, Phragmites australis and Phragmites mauritianus, are harvested in the three villages. These are used in the construction of building material (roofing), courtyard fences, and in making mats and some fishing equipment. Phragmites mauritianus (also known as the common reed) is spinier, taller and more productive than Phragmites australis. Table 2 shows the number of bundles harvested by households and the estimated household direct use value of river reed in each of the three villages, using the prices as recorded during the survey. This price was converted to US\$ according to the average exchange rate for 2003, i.e. 0.204050 US $\$=1$ Botswana Pula. 


\section{Table 2}

Harvesting period, annual harvests and estimated household value in US\$ of river reed in Shakawe, Etsha-13 and Shorobe during 2003

\begin{tabular}{|l|c|c|c|}
\hline Variable & Shakawe & Etsha-13 & Shorobe \\
\hline Harvesting period & Aug-Dec & Dec-Feb & Aug-Jan \\
Household's annual harvest & 126 bundles & 43 bundles & 258 bundles \\
Price/bundle (US\$)* & 4.08 & 4.08 & 4.08 \\
Value per household (US\$) & 514.21 & 175.48 & 1052.90 \\
\hline
\end{tabular}

* 0.204050 US\$ = 1Botswana Pula (2003)

As shown in Table 2, the value of reeds to households was greatest in Shorobe because more bundles per household were being harvested there. An average household in Shorobe harvested twice the bundles of river reed that a household in Shakawe gathered, and about six times the number of bundles harvested by an average household in Etsha-13. Because the harvesting site is further away from the village $(25 \mathrm{~km})$, harvesters migrate to and stay at the harvesting site for a period of about two and a half months, enabling them to devote more time to harvesting. Conversely, households in Shorobe devote more time to harvesting than do those in Shakawe and Etsha-13.

\section{Thatching grass}

The main thatching grass species harvested at Shakawe and Etsha-13 is Miscanthus junceus. A bundle of Miscanthus junceus measures about $850 \mathrm{~mm}$ in diameter and weighs about $10 \mathrm{~kg}$. In Shorobe, households harvest Cymbopogon excavatus. A bundle of Cymbopogon excavatus has a diameter of approximately $500 \mathrm{~mm}$ and weighs about $4.5 \mathrm{~kg}$. Table 3 shows the number of bundles harvested by a household and the direct use value of grass in each village. As with river reed, households in Shorobe harvested more bundles of thatching grass than those in the other two villages. An average household in Shorobe harvested 1.5 times the number of bundles harvested by a household in Shakawe, and about four times the number of bundles harvested by an average household in Etsha-13.

Table 3

Household value of thatching grass in Shakawe, Etsha-13 and Shorobe during 2003

\begin{tabular}{|l|c|c|c|}
\hline Variable & Shakawe & Etsha-13 & Shorobe \\
\hline Harvestable grass species & Miscanthus & Miscanthus & $\begin{array}{c}\text { Cymbopogon } \\
\text { excavatus }\end{array}$ \\
Harvesting period & junceus & junceus & Jul-Oct \\
Household's annual harvest & Aug-Dec & Dec-Feb 64 & bundles \\
Price/bundle* & 168 bundles & 4.08 & 257 bundles \\
Value per household (US\$) & 4.08 & 261.18 & 4.08 \\
\hline
\end{tabular}

* 0.204050 US\$ = 1Botswana Pula (2003)

\section{Palm leaves (Hyphaene petersiana)}

The leaves of Hyphaene petersiana (real fan palm) are used in making baskets. The leaves are combined with other plant products to improve the quality and marketability of the baskets. For instance, the roots and/or bark of Berchemia discolor (bird plum) are used to produce a red dye, while those of Euclea divinorum (the 
diamond leaved Euclea) are used to produce a brownish dye.

Hyphaene petersiana leaves are harvested throughout the year. According to groups in discussions, the majority of the basket-makers harvest the leaves of this tree for their own use rather than for sale, as they make baskets for private sale. The harvested leaves are cooked, dried and tied into small bundles. A single dried bundle is made up of approximately five leaves and weighs about $0.037 \mathrm{~kg}$. According to the reported frequency of harvesting, a basketmaker harvests about $2.2 \mathrm{~kg}$ palm leaves per year. The price of a single bundle was US $\$ 0.41$ on the local market during 2003. A kilogram of dry palm leaves therefore cost about US $\$ 11.02$ in 2003. Table 4 shows the average value of palm leaves in the three villages.

\section{Wild fruits and edible plant parts}

Households in the three villages reportedly harvested fifteen different species of wild fruits. The main wild fruits and edible plant parts (mostly the roots) sold on the market are Strychnos cocculoides (Corky monkey orange), Strychnos pungens (Spine-leaved monkey orange), Grewia bicolor (false brandybush), Grewia flava (Brandy-bush), Garcinia livingstonei (African mangosteen), Berchemia discolour (Bird plum) and Nymphaea caerula (Water Lily).

An average household harvests about ten fruits of Strychnos cocculoides and ten fruits of Strychnos pungens twice a month during the harvesting period. A single fruit of each of these two plants weighs about $0.2 \mathrm{~kg}$ and was sold for US\$0.20 in 2003. A household harvested a total mass of about $2 \mathrm{~kg}$ of the Water Lily (Nymphaea caerula) tubers, at a frequency of four times during the harvesting season. A tuber of Nymphaea caerula (weighing on average $0.150 \mathrm{~kg}$ ) was sold for US\$0.10 during 2003 . As far as Grewia bicolor, Grewia flava, Garcinia livingstonei and Berchemia discolor were concerned, group discussions indicated that the harvesting frequency of an average household was about twice during the harvesting period. A harvester therefore harvested about $2 \mathrm{~kg}$ of fruit of each species. A cupful of each fruit sold for about US\$0.2 on the local market in 2003.
Using four months as an average harvesting period and the different collection frequencies for different wild fruits and plants, the total amount of fruits and edible plant parts of Grewia bicolor, Grewia flava, Garcinia livingstonei and Berchemia discolour collected by a household was estimated at $128 \mathrm{~kg}$. Using an average market price of US $\$ 0.89 / \mathrm{kg}$ for all saleable fruits and edible plant parts, the average annual household value for this collection was calculated to be US\$114.92 (see Table 4).

\section{Fuelwood}

A large number of households in the three villages depend on fuelwood as their main source of energy. The preferred species of fuelwood are Diospyros mespiliformis (African ebony), Teminalia sericea (Silver-leaf teminalia), Acacia erubescens (Black thorn), Combretum collinum (Bicoloured bush willow), Acacia negrescens (Knob thorn), Combretum imberbe (Lead wood), Baikiaea plurijuga (Rhodesian teak), Dichrostachys cinerea (Sickle bush), Guiboutia coleosperma (False mopane), Colophospermum mopane (Mopane), Acacia tortilis (Umbrella thorn), Erythrophleum africanum (Ordeal tree), Euclea undulata (Diamond-leaved euclea), Ximenia caffra (Large sourplum), Ziziphus mucronata (Buffalo thorn), Pterocarpus angolensis (Mukwa), Lonchocarpus capassa (Rain tree), Garcinia livingstonei (African Mangosteen), Croton megalobotrys (Fever berry) and Bocia albitrunca (Shepherd Tree). Households in all three villages reported collecting only dead wood. The majority of the households gather fuelwood in bundles which people then carry on their heads. A few households use donkey carts to carry fuelwood. A bundle of fuelwood weighs about $12 \mathrm{~kg}$, while a single-axle donkey cart load weighs about $350 \mathrm{~kg}$ (Kgathi, 1984). About 29 bundles of fuelwood can thus fill a single-axle donkey cart. Group discussions revealed that, on average, a bundle of fuelwood lasts up to 3 days. The fuelwood requirements for a week during nonwinter months were therefore estimated at 28 $\mathrm{kg}$. Assuming a 30 percent annual increase in fuelwood consumption during the winter months, the weekly fuelwood requirement for a household translates into $34.4 \mathrm{~kg}$. The annual 
household fuelwood requirement is about 1 $892.8 \mathrm{~kg}$. According to group discussions, a single-axle donkey cartload of fuelwood was priced at US\$ 9.18 or US\$ $0.027 / \mathrm{kg}$ in 2003 .
Based on this information, the annual household direct use value of fuelwood was estimated at US\$49.79 during 2003 (see Table 4).

\section{Table 4}

Average household direct use value of palm leaves, wild fruits and edible plant parts, and fuelwood for the three villages during 2003

\begin{tabular}{|l|c|c|c|}
\hline Variable & Palm leaves & $\begin{array}{c}\text { Wild fruits and } \\
\text { edible plant parts }\end{array}$ & Fuelwood \\
\hline Household's annual harvest (kg) & 2.2 & 128 & 1892.8 \\
Price/kg (US\$)* & 11.02 & 0.90 & 0.027 \\
Value per household (US\$) & 24.24 & 114.92 & 49.79 \\
\hline
\end{tabular}

* 0.204050 US\$ = 1Botswana Pula (2003)

\section{Total for three study sites}

The total contribution of resource extraction to community livelihood is shown in Table 5. The total value of the resources harvested in 2003 for the three villages is estimated as US\$1,4 million, the contribution of thatching grass being the highest (49 percent) followed by river reed ( 40 percent). At a discount rate of 8 percent, the present value of the benefits derived from the free harvest of extractable material is US $\$ 17,7$ million. Given the size and the comparatively high resource extraction rates of Shakawe, the direct use value comprises 84 percent of that total. The weighted average value of the resources extracted per household is estimated at US\$834.48 per year. This figure is 35 percent of the country's average disposable income per capita (US\$2 389) and almost 60 percent of that of the average household income for the three villages. This indicates the significant contribution to the livelihood of rural communities made by the direct extraction of harvested resources.

Table 5

Value of the direct use of harvested resources for the three studied villages during 2003

\begin{tabular}{|l|r|r|r|r|}
\hline & \multicolumn{3}{|c|}{ Village } & $\begin{array}{r}\text { Weighted average value per } \\
\text { household for all villages for } \\
\text { all households (US\$) }\end{array}$ \\
\cline { 2 - 4 } & Shakawe & Etsha-13 & Shorobe & $\begin{array}{r}\text { (U) } \\
\text { Value per household (US\$): }\end{array}$ \\
Fuelwood & 49.79 & 49.79 & 49.79 & 46.06 \\
River reed & 514.21 & 175.48 & 1052.9 & 331.68 \\
Thatching grass & 685.61 & 261.18 & 1048.82 & 412.01 \\
Palm leaves & 24.24 & 24.24 & 24.24 & 7.50 \\
Wild fruits and edible plant parts & 114.92 & 114.92 & 114.92 & 40.23 \\
\cline { 1 - 3 } Number of households & 1096 & 345 & 242 & \multirow{2}{*}{ Total: } \\
\hline
\end{tabular}




\begin{tabular}{|c|c|c|c|c|c|}
\hline \multicolumn{6}{|l|}{$\%$ of households using resource: } \\
\hline Fuelwood & 92 & 98 & 87 & & \\
\hline River reed & 81 & 67 & 24 & & \\
\hline Thatching grass & 81 & 49 & 16 & & \\
\hline Palm leaves & 27 & 42 & 33 & & \\
\hline Wild fruits and edible plant parts & 45 & 25 & 4 & & \\
\hline Value for all households: & & & & Total & $\%$ contribution \\
\hline Fuelwood & 50204 & 16834 & 10483 & 77521 & $5 \%$ \\
\hline River reed & 456495 & 40562 & 61152 & 558210 & $40 \%$ \\
\hline Thatching grass & 608657 & 44152 & 40610 & 693420 & $49 \%$ \\
\hline Palm leaves & 7173 & 3512 & 1936 & 12621 & $1 \%$ \\
\hline Wild fruits and edible plant parts & 56679 & 9912 & 1112 & 67703 & $5 \%$ \\
\hline Total & 1179208 & 114973 & 115294 & 1409,475 & \\
\hline$\%$ contribution & $84 \%$ & $8 \%$ & $8 \%$ & & \\
\hline
\end{tabular}

\section{Results for the Delta as a whole}

In Table 6, we show the overall direct use value of plant products estimated for the entire Okavango Delta and the value per hectare of each resource during 2003. These values are derived from multiplying the unit values, as determined above, with the number of households utilising the respective resources. The overall total direct use value of plant resources was estimated at US\$8 152063 , which translates into US $\$ 43.41 /$ ha or US $\$ 1424$ per household, slightly more than the average annual household income in the area. The net present value of the total direct benefit of harvesting resources from the wild at a discount rate of 8 percent is US\$101.9 million. The total direct use value is underestimated because it included only plant products that are marketed. The estimated direct use value of river reed was the highest (US\$29.00/ha), while the direct use value of palm leaves was the lowest (US\$0.31/ ha). In terms of the contribution of each of these resources to household livelihood, the highest benefit was derived from grass (US\$665.20). The contribution of each of the resources to household livelihood was grass (27.84 percent), reeds ( 24.25 percent), wild fruits and edible plant parts (4.81 percent), fuelwood (2.1 percent) and palm leaves (1.01 percent), respectively.

\section{4}

\section{Discussion and conclusion}

In 2003, the total direct use value for harvested resources was US\$8,1 million, which translates to a net present value of US $\$ 101,9$ million, using a discount rate of 8 percent. The direct use value of selected vegetation resources discussed in this study was estimated at US\$43.41/ha or US\$1 434 per household. The values are underestimated, as not all the ecosystem goods and services have been considered. The direct use values are therefore probably in excess of the estimated total value per hectare (US $\$ 43.41$ / ha). For instance, when considering the value of tourism, as estimated by Mmopelwa and Blignaut (2006), the value of the Delta increases to US\$73.58/ha. Comparing these estimates to the average annual disposable income of the study area, which is US\$1 614, it is clear that resource extraction contributes significantly to household livelihood. 


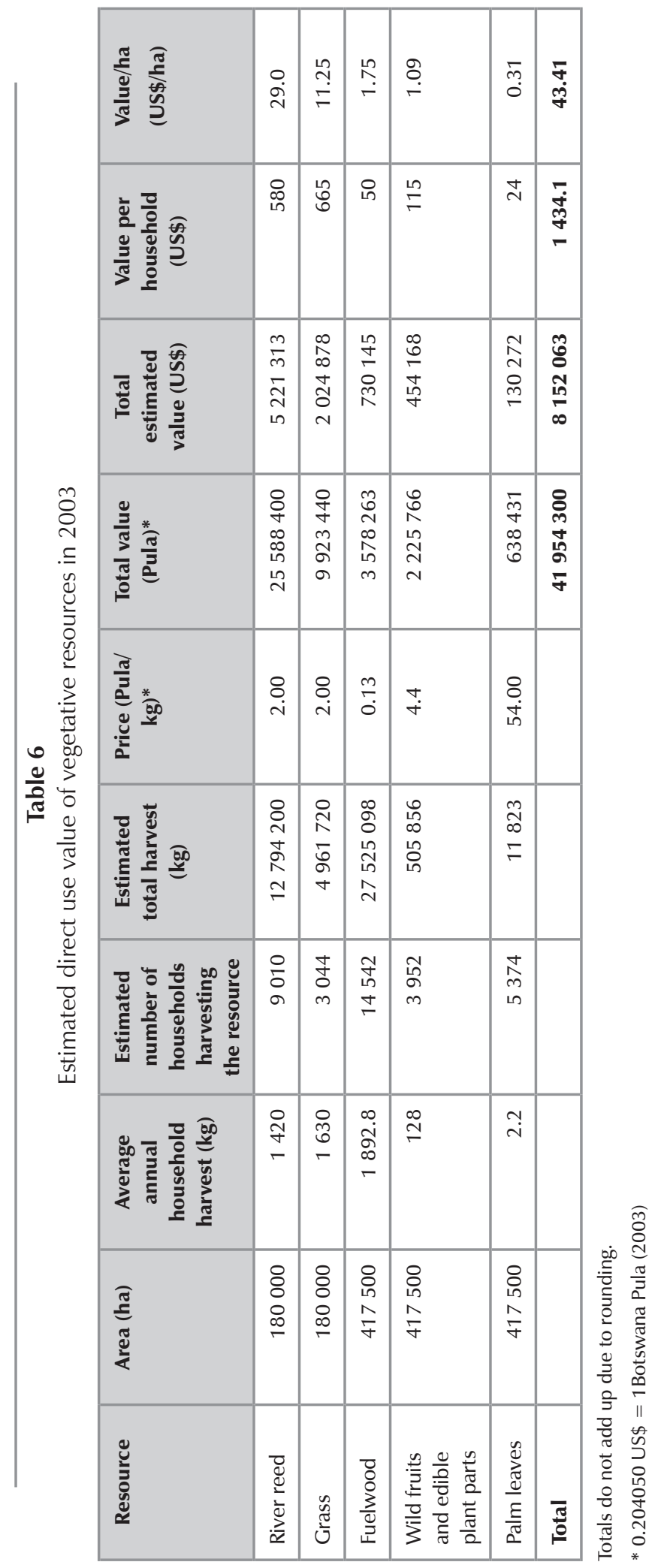


The estimated value per hectare of vegetative resources reported in this study make it possible to compare these estimated values with those of similar wetlands resources obtained from studies done in other parts of the world. As shown in Table 7, the values per hectare in the Okavango Delta are generally higher than the corresponding values in other wetlands in southern Africa, such as the Barotse Floodplain and the Chobe Caprivi wetlands (see Turpie et al., 1999). The differences in the estimated values are mainly owing to the fewer amounts of resources harvested per household in these other wetlands. Essentially, the greater number of resources harvested in the Okavango Delta translates into the higher direct use values of the resources.

\section{Table 7}

Direct use value, US\$/ha, of selected vegetation resources in some case studies in southern Africa

\begin{tabular}{|c|c|c|c|c|}
\hline & Okavango & Barotse & Caprivi Chobe & $\begin{array}{c}\text { Notes/explanation of } \\
\text { differences }\end{array}$ \\
\hline Source: & This study & $\begin{array}{l}\text { (Turpie et al., } \\
\text { 1999) }\end{array}$ & $\begin{array}{l}\text { (Turpie et al., } \\
\text { 1999) }\end{array}$ & \\
\hline Fuelwood & 1.75 & Not estimated & Not estimated & \\
\hline Reed & 29.0 & 0.25 & 0.75 & $\begin{array}{l}\text { Households harvest fewer } \\
\text { quantities of reeds in Barotse } \\
\text { Floodplain and Chobe Caprivi } \\
\text { wetlands }\end{array}$ \\
\hline Grass & 11.25 & 0.4 & 0.59 & $\begin{array}{l}\text { Households harvest fewer } \\
\text { quantities of grass in Barotse } \\
\text { and Chobe Caprivi wetlands }\end{array}$ \\
\hline $\begin{array}{l}\text { Wild fruits and } \\
\text { edible plant } \\
\text { parts }\end{array}$ & 1.09 & $\begin{array}{l}\text { Estimated as } \\
\text { part of all wild } \\
\text { foods }\end{array}$ & $\begin{array}{l}\text { Estimated as } \\
\text { part of all wild } \\
\text { foods }\end{array}$ & $\begin{array}{l}\text { Estimated as part of all wild } \\
\text { foods }\end{array}$ \\
\hline Palm leaves & 0.31 & 0.0033 & 0.074 & $\begin{array}{l}\text { Fewer quantities of palm } \\
\text { leaves harvested by an average } \\
\text { household in the Barotse and } \\
\text { Chobe Caprivi wetlands }\end{array}$ \\
\hline
\end{tabular}

The free harvesting of resources from the wild within the proximity of the Okavango Delta represents a very significant contribution to household livelihood in rural areas. Resource harvesting constitutes an "in kind" income approximately equal to that of the average financial income in the region, and acts as an important livelihood "safety net". In other words, it reduces a household's vulnerability to environmental and economic changes, as it diversifies the source of livelihood. Should the wetland be degraded, whether by commercial exploitation, over-harvesting of resources, or any other means, the impact on the livelihood of households is likely to be significant. Given the limited number of other means available to households to support themselves, their ability to adapt to such degradation is also likely to be limited.

As the values can be used to raise awareness among decision-makers of the economic benefits of conserving and sustainably managing the Okavango Delta, the Government of Botswana should consider these values as initial cost to the society if the Delta is not sustainably managed. Thus, the perception that wetlands are without value is incorrect. The government should therefore conserve the Delta, ensuring 
its continued provision of ecosystem goods and services to current and future generations.

\section{References}

\section{APPLIED DEVELOPMENT RESEARCH}

CONSULTANTS (ADRC), 2001. A report on the socioecological survey of the Okavango Basin. Gaborone:

Kalahari Conservation Society.

ASHTON, P.J., NORDIN, L. \& ALONSO, L.E., 2003. Introduction to the Okavango Delta and the AquaRap expedition. In: Alonso, L.E. \& Nordin, L. (Eds). A rapid biological assessment of the aquatic ecosystems of the Okavango Delta, Botswana: High Water survey. RAP Bulletin of Biological Assessment No. 27. Washington, DC: Conservation International.

BARBIER, E.B., ACREMEMAN, M. \& KNOWER, D., 1997. Economic valuation of wetlands: guide for policy and planners. Gland: Ramsar Convention Bureau. BOYER, T. \& POLASKY, S., 2004. Valuing urban wetlands: a review of non-market valuation studies. Wetlands, 24(4): 744-755.

BRANDER, L.M., RAYMOND, J.G.M.F. \& VERMAAT, J.E., 2006. The empirics of wetland valuation: a comprehensive summary and a metaanalysis of the literature. Environmental and Resource Economics, 33: 223-250.

CENTRAL STATISTICS OFFICE (CSO), 2001. Population of town, villages and associated localities. Gaborone: Government Printer.

ELLERY, K. \& ELLERY, W.N., 1997. Plants of the Okavango Delta: a field guide. Durban: Tsaro Publishers. EMERTON, L., 1998. Economic tools for valuing wetlands in eastern Africa. Nairobi: International Union for the Conservation of Nature.

GOVERNMENT OF BOTSWANA, 2001. Botswana national atlas. Gaborone: Department of Surveys and Mapping.

GOVERNMENT OF BOTSWANA, 2003. Budget speech delivered to the National Assembly on 3 February by the Minister of Finance and Development Planning, Gaborone, Botswana.

GUMBRICHT, T., WOLSKI, P., FROST, P. \& MCCARTHY, T.S., 2004. Forecasting the spatial extent of the annual flood in the Okavango Delta, Botswana. Journal of Hydrology, 290: 178-191.

HEAL, G., 2004. Valuing ecosystem services: toward better environmental decision-making. Washington, DC: National Academic Press. Available at: http:// www.nap.edu (accessed on 14 November (2006). HUDSON-MURRY, M. \& PARRY, D., 1997. Environmental studies: the permanent Okavango River Basin Water Commission (OKACOM) assessment. Maun: OKACOM.
JANSEN, R., 2002. The Okavango Delta Management Plan: application of an ecosystem based planning approach. Paper presented at the Seventh Global Biodiversity Forum, Valencia, Spain, 15-17 November. KGATHI, D.L., 1984. Aspect of fuelwood trade between rural Kweneng and urban Gaborone: a socio economic perspective. Gaborone: National Institute of Development Research and Documentation (NIR), University of Botswana.

KGATHI, D.L., BENDSEN, H., BLAIKE, P., MBAIWA, J., NGWENYA, B.N. \& WILK, J., 2004. Rural livelihoods, indigenous knowledge systems, and political economy of access to natural resources in the Okavango Delta. Maun: Harry Oppenheimer Okavango Research Centre, University of Botswana. MASUNDIRE, H., RINGROSE, S., SEFE, F.T.K. \& VAN DER POST, C., 1998. Botswana wetlands policy and strategy: inventory of wetlands of Botswana. Gaborone: National Conservation Strategy Agency \& Ministry of Local Government, Lands and Housing. MCCARTHY, T.S., 1997. Specialist Report on the Okavango Delta and its floodplain system in Botswana. Windhoek: Water Transfer Consultants \& Department of Water Affairs.

MILLENNIUM ECOSYSTEM ASSESSMENT, 2003. Ecosystem and human well-being : a framework for assessment. World Resources Institute. Washington: Island Press.

MMOPELWA, G., 2006. Economic and financial analysis of harvesting and utilisation of river reed in the Okavango Delta, Botswana. Journal of Environmental Management, 79(4): 329-335.

MMOPELWA, G. \& BLIGNAUT, J.N., 2006. The Okavango Delta: the value of tourism. South African Journal of Economic and Management Sciences, 9(1): 113-127.

MONNA, S.C., 1999. A framework for international cooperation for the management of the Okavango Basin and Delta. Ramsar COP7 DOC.205. The Ramsar Convention on Wetlands. Available at: http:// www.ramsar.org/cop7_doc_20.5_htm (accessed on: 1/12/08).

NEME, L.A., 1997. The power of the few: bureaucratic decision making in the Okavango Delta. The Journal of Modern African Studies, 35(1): 37-51.

PEARCE, D.W. \& TURNER, R.K., 1990. Economics of natural resources and the environment. New York: Harvester Wheatsheaf.

PLANTEC AFRICA, 2003. Ngamiland district settlement strategy 2003-2027. Gaborone: Ministry of Lands and Housing.

PRATO, T., 1998. Natural resource and environmental economics. Iowa: Iowa State University Press. 
ROTHERT, S., 1997. Which way the Okavango Delta? In proceedings of a national conference on conservation and management of wildlife in Botswana: strategies for the twenty first century, Department of Wildlife and National Parks and Kalahari Conservation Society, Gaborone, 13-17 October.

ROTHERT, S., 1999. Meeting Namibia's water needs while sparing the Okavango. San Francisco: International Rivers Network and Conservation International.

SCHUDDER, T., MANLEY, R.E., COLEY, R.W., DAVIS, R.K., GREEN, J., HOWARD, G.W., LAWRY, S.W., MARTZ, D., ROGERS, P.P., TAYLOR, A.R.D., TURNER, S.D., WHITE, G.F. \& WRIGHT, E.P., 1993. The IUCN Review of the Southern Okavango integrated water development project. Gland: International Union for the Conservation of Nature. SILVIUS, M.J., ONEKA, M. \& VERHAGEN, A., 2000. Wetlands: lifeline for the people at the edge. Physics, Chemistry and Earth, 25(7-8): 645-652.

\section{SNOWY MOUNTAINS ENGINEERING}

CORPORATION, 1987. Southern Okavango Integrated Water Development. Final Report. Gaborone: Ministry of Mineral Resources and Water Affairs. STUIP, M.A., BAKER, C.J., \& OOSTERBERG, W., 2002. The socio-economic of wetlands. Wageningen: Wetlands International and RIZA. Available at: http:// www.wetland.org/pubs\&/pub_online/SocioEsc/Part1. pdf (accessed on 13 August 2008).

TURNER, R.K., VAN DEN BERG, J.C.J.M., SODERRQVIST, T., BARENDREGT, A., STRATEN, J.V.D., MALTBY, E. \& VAN IRELAND, E.K., 2000. Ecological economic analysis of wetlands: scientific integration for management and policy. Ecological Economics, 35(1): 7-23.

TURPIE, J., SMITH, B., EMERTON, L. \& BARNES, J., 1999. Economic values of the Zambezi Basin wetlands. Harare: IUCN Regional Office for Southern Africa. 